\section{Research councils identify gaps in Europe's science}

[MUNICH] Science in Europe is relatively weak compared to other countries particularly the United States - in astroparticle physics, organic synthesis, fuel cell chemistry and the study of coastal ecosystems. These are some of the gaps that have been identified in the first survey analysing the strengths and weaknesses of European research, which was carried out under the auspices of the heads of European research councils and published last week.

The survey also confirms some familiar concerns. These include the lack of mobility of researchers, insufficient interdisciplinary research and a poor record of technology transfer coupled with lack of access to venture capital. It places particular stress on the declining stability of career structures for young scientists.

One of the scientific gaps identified by the survey was in classical optics, where Europe has previously played a leading role. The survey reported that Europe had lost its competitive edge to the United States in image processing and image recognition, and the storage of optical information. Another gap is in tropospheric chemistry, where the survey says technological advances in laser techniques and spectroscopy have not been applied.

The survey was carried out by Eurohorcs, an informal group of research council heads, at the request of the European Science and Technology Assembly (ESTA), the European Commission's advisory body (see Nature $383,659 ; 1997)$. It is intended to help ESTA to identify weaknesses that could harm the competitive potential of Europe.

But the speed of the exercise - the survey was completed within two months - and the resulting variation in the quality of input has led some science policy experts to question its value.

The survey results are being circulated to professional organizations for comment, and will be discussed at the next ESTA meeting in July. Jan Borgman, the assembly's chairman, says it will use these comments to help gauge how much authority to give each of the reports.

Some of the scientific gaps identified in the survey will then be presented to the commission "to see how it responds". Borgman hopes that this can be done in time to influence the contents of the commission's fifth Framework research programme, which is due to be launched next year.

Despite the survey's weaknesses, Borgman says he is pleased with "this first attempt of the scientific community to design its own future".

Alison Abbott

\title{
Budget mismatch worries Australian scientists
}

[CANBERRA] Research leaders in Australia are expressing concern about an apparent mismatch between government claims that its budget, released last week, includes a growth in science funding, and official background documents showing a decline in real terms.

Joe Baker, president of the Federation of Australian Scientific and Technological Societies, says it was "absolutely amazing" that in his budget speech, Peter Costello, the Treasurer, had made "no reference to education, science, technology or innovation".

The speech contrasted sharply with a public commitment made three months earlier by the Prime Minister, John Howard, that the "central" role of science and technology "will never be ignored so far as my government is concerned".

In a statement issued on budget night, the minister for science and technology, Peter McGauran, said the government intended to increase direct Commonwealth spending for science and innovation by $\mathrm{A} \$ 43$ million (US\$33 million) in 1997-98, to a total of A $\$ 3.55$ billion (see Nature 387, 222; 1997).

In particular, he said that the Commonwealth Scientific and Industrial Research Organisation (CSIRO), Australia's chief science agency, would receive a five per cent increase in funding to $\mathrm{A} \$ 473$ million.

But the minister's annual Science and Technology Statement, and his department's Portfolio Statement, both released later, reveal that when the sums are converted to constant dollars, there will be a decrease of A $\$ 38$ million - or 1.3 per cent - in the year beginning 1 July.

Even more alarming to researchers has been an unannounced recalculation of the cuts from the 1996-97 budget. These were predicted at the time to represent 5.1 per cent in real terms, but the actual effect has been nearly twice as much - 9.6 per cent the largest cut since statistics began.

The apparent overall increase for next year came largely from an extra $\mathrm{A} \$ 33.7$ million added to the budget for CSIRO, and A \$6.7 million added for the Australian Nuclear Science and Technology Organisation (ANSTO). But detailed analysis shows that there will actually be no increase in operating funds for either agency in the coming year.

In CSIRO's case, the apparent funding increase results from a delay in returning to the government funds obtained from asset sales that the research organization was required to make in last year's budget.

CSIRO will also feel the effect of a A $\$ 10$ million cut over two years in the Cooperative Research Centres (CRCs) programme, in which it is the major partner. It must also achieve an 'efficiency dividend' of one per cent on its non-research and development activities, amounting to a $\mathrm{A} \$ 1.25$-million cut.

When cuts announced to CRCs were not as great as had been rumoured, McGauran claimed that "there were champagne corks popping all around the CRCs". But a sense of celebration was missing from CRC directors, who expect that the number of centres will be reduced, and have warned that the cuts will "take away all the government's unallocated funds in future years".

The increase for ANSTO is entirely for the reprocessing of spent fuel rods at Dounreay in Scotland.

PeterPockley

\section{Germany plans 'unique' centre for Bonn}

[MUNICH] Plans for a major new interdisciplinary research centre in Bonn were approved last week by Germany's Science Council, the Wissenschaftsrat. The new centre will be unique among federally supported research institutes in having the freedom to select and change its research areas at short notice.

The Centre of Advanced European Studies and Research (CAESAR) will begin work in temporary accommodation next year. It has been set up with part of a DM1.6billion (US\$950-million) federal grant intended to develop the Bonn region as a major science area, in compensation to the city for the German government's move to Berlin (see Nature 374, 109; 1995).

CAESAR will be funded from a DM750- million capital foundation. Most of this comes from the federal grant, which will be made available in instalments until 2004, and DM190 million of this will be spent on a new building and equipment. Interest from the remaining sum will support an international staff of around 150 scientists, all of whom will be hired on short-term contracts, with a maximum stay of ten years. An additional 150 scientists funded from other sources may also be accommodated.

The scientists will work in 60 small groups on "technologies of the twenty-first century", such as nanoscience, biotechnology and informatics.

Each group will work closely with industry and other international research institutions. 